\title{
Erratum to: Probabilistic Analysis of Suture Lines Developed in Ammonites: The Jurassic Examples of Hildocerataceae and Hammatocerataceae
}

\author{
Andrea Di Cencio $^{1}$. Serena Doria ${ }^{1}$
}

Published online: 18 January 2017

(C) International Association for Mathematical Geosciences 2017

\section{Erratum to: Math Geosci DOI 10.1007/s11004-016-9666-6}

The original version of this article unfortunately contained a mistake. On page 2 the spelling of the 3 species was incorrect. The correct names are:

Pleydellia buckmani Maubeuge, 1947

Geczyceras speciosum (Janensch, 1902)

Cenoceras toarcense (d'Orbigny, 1842)

The online version of the original article can be found under doi:10.1007/s11004-016-9666-6.

$凶 \quad$ Andrea Di Cencio

andreadicencio@geologiaepaleontologia.eu

1 Department of Engineering and Geology University, G.d'Annunzio, Chieti, Italy 